\title{
Which Transparency Matters? Compliance with Anti- Corruption Efforts in Extractive Industries
}

\begin{abstract}
The Extractive Industries Transparency Initiative (EITI) sets the standard in revenue transparency in 46 countries and works under the assumption that compliance with the initiative will improve transparency and curb corruption in member states. However, individual case studies raise doubts about the success of the initiative. Building upon the literatures on compliance and governance, this paper analyzes the impact of EITI membership on transparency and corruption levels between 2006 and 2013. By using interrupted time series and panel data analyses, this research makes an original contribution to show that affiliation with the EITI immediately improved overall aggregate data disclosure in member countries in this period. At the same time, the paper also shows that perceptions of corruption did not change. This outcome questions the effectiveness of promoting only a narrow definition of transparency in extractive industries as a measure to prevent corruption. The results imply that a more comprehensive treatment of transparency might be necessary; specifically to distinguish regimes that use transparency reforms for public relations purposes as opposed to genuine reformers.
\end{abstract}

Keywords: Transparency, Compliance, Extractive Industries, Corruption, Governance, International Organizations

\section{Introduction}

In the last decade transparency has become a global phenomenon. Now, even countries with questionable records of good governance seek compliance with global transparency norms. This trend is especially evident in the extractive industries; where international financial institutions (IFIs) promote transparency in order to help countries better manage their resources. In particular, the Extractive Industries Transparency Initiative (EITI), currently implemented in 46 countries, sets the standard in revenue transparency. The main assumption of the EITI process is that compliance with the initiative will improve transparency and curb corruption in member states. However, individual case studies raise doubts about the overall success of the initiative especially with regards to battling corruption. Does the EITI process actually help improve transparency and curb corruption?

This research addresses this question by focusing on the effectiveness of transparency promotion. It analyzes the impact of EITI membership on transparency and 
corruption levels between 2006 and 2013 by using interrupted time series and panel data analyses. It makes an original contribution to the literatures on governance and compliance to show that affiliation with the EITI improved overall economic transparency in member countries in this period. At the same time, the paper also shows that the EITI membership did not have a visible impact on perceptions of corruption. I argue that this outcome is mostly due to the narrow definition of transparency adopted by the EITI before 2013, which failed to address corruption in the broader resource management process and the economy as a whole. As a result, even if many EITI members successfully complied with the EITI standard, major corruption networks remained intact.

The first section of the paper analyzes the link between transparency and corruption in the extractive industries. The next section examines the EITI as the most significant external agent of transparency promotion. The following sections introduce the analytical framework, the model, and the results. The last part of the paper discusses the implications of the results for resource-rich countries.

\section{Is Transparency a Remedy for Corruption?}

One of the main impacts of natural resource abundance is the creation of excess revenues above normal profits, or rents. In many developing countries, this process may encourage shortsightedness and rent-seeking behavior by the politicians, which weakens the state capacity. These rentier states often fail to function as a 'state' in the conventional sense of

providing security, well being, and identity to its citizens in exchange for taxes and certain national services. They instead show many symptoms of underdevelopment such 
as corruption, lack of rule of law, and dysfunctional bureaucracies (Beblawi, 1987; Mahdavy, 1970; Mehlum, Moene, \& Torvik, 2008). As a consequence, in many resourceexporting countries, rulers fail to address problems of economic development, income inequality, regional disparities, health care, and education despite high revenues from extractive industries.

The literature on good governance argues that well-functioning institutions can offset these predatory development policies and reduce patronage and corruption in resource-rich countries (Mehlum, Moene, \& Torvik, 2006). This institutional focus on the implications of resource dependency primarily relates to democratization. This perspective may suggest that as resource-rich countries become more democratic, corruption will cease to be a major problem. However, the experience of many authoritarian oil states in the Gulf reveals that, despite the claims of the modernization theory (Dahl, 1971; Huntington, 1993; Lipset, 1959), democratization is not an automatic process. Indeed, oil wealth may actually adversely affect democracy (Jensen \& Wantchekon, 2004; Korhonen, 2004) and lengthen authoritarian regimes (Ross, 2001, 2008). Furthermore, political leaders of many authoritarian resource-rich countries zealously block any political openings (Deese, 2003).

In the last decade, transparency emerged as a popular catchphrase in good governance literature to provide an alternative to head-on democratization and regime change. Transparency is easier to implement relative to full-scale democratization because it does not alter the balance of power in the host country or deprive the privileges of the elites. Primarily, transparency acts as a precipitator, which leads to better decisions, policies, and processes without causing a fundamental shift in the political 
regime. In theory, it also facilitates "cooperation over opportunistic rent-seeking and help maintain norms of integrity and trust” (Kolstad \& Wiig, 2009, p. 529).

Despite its growing global appeal, it is actually difficult to find a common definition of transparency since it can apply to policy-making processes, policy outcomes, institutions, and various forms of information flows. In this research, I will use the categorization by Hollyer, Rosendorff and Vreeland (2014a) in order to meaningfully discuss different forms of transparency and their relative impact on corruption. They identify three aspects of transparency relevant to government policies. The first one is institutional transparency, which signifies the relative openness of government institutions and the policy-making processes. In other words, it concerns the amount of information citizens possess on the way governments carry out their policies. This aspect of transparency is often difficult to measure; yet it may be partially captured by indices of democracy (Broz, 2002), studies of central bank independence and freedom of information laws (Berliner, 2014; Chortareas, Stasavage, \& Sterne, 2002; Islam, 2006), or in-depth case studies (Öge, 2014, 2015).

The second aspect of transparency is media openness. A free and well-functioning media can both contribute to knowledge creation and disseminate existing information to a broader audience. This type of transparency is measured by freedom of the media indices (Brunetti \& Weder, 2003). Finally, the third aspect of transparency is aggregate data disclosure by governments (Hollyer et al., 2014a). Data disclosure informs the general public on the broad policy outcomes that affect the welfare of the population as a whole. This type of data is crucial in order to assess government performance in key policy areas as economic growth, income inequality, etc. 
How does transparency affect corruption? In extractive industries, corruption might take the form of bribes from foreign actors in exchange for preferential treatment (Franke, Gawrich, \& Alakbarov, 2009, pp. 125-127), clandestine deals with private firms that are organically tied to the political leadership (Gleason, 2010, p. 78), illegal transfers from the national stability fund to private offshore accounts (Bohr, 2003; Esanov, Raiser, \& Buiter, 2001, p. 5), nepotism in key bureaucratic positions (Peyrouse, 2012, p. 112), and payments to individuals or groups in exchange for their loyalty to the regime (Kalyuzhnova \& Bluth, 2008, p. 55).

Despite its evident qualities, the impact of transparency on corruption is not established, mostly due to problems of definition and measurement. Among different aspects of transparency mentioned above, institutional transparency is best equipped to address corruption and inefficiency in the extractive industries because it applies to how governments actually manage their natural resources. This form of transparency can undermine bribery and embezzlement in different stages of the resource management process by making such acts riskier, by providing good incentives to public officials, and by initiating a fair selection process for public servants. In contrast, a less transparent institutional environment would reduce scrutiny and removing incentives for reform. Islam, for example, shows that better access to government is correlated with higher governance levels (2006). Institutional transparency may also help democratization, by allowing the public to hold politicians accountable for their actions (Kolstad \& Wiig, 2009, p. 529).

Transparency as media openness can also contribute to anti-corruption efforts by uncovering cases of misappropriation and nepotism. In fact, a negative correlation exists 
between corruption and transparency when the latter is a measure of the freedom of press in a country (Brunetti \& Weder, 2003). However, media is often constrained by its resources and ability to collect information (Hollyer et al., 2014a). This limitation is likely to manifest itself in extractive industries, which often operate in secrecy.

Finally, transparency as disclosure of aggregate data is probably the least effective remedy to corruption compared to other forms of transparency. The form of transparency helps present an overall picture of the economy; however, the aggregate nature of the data makes it difficult to capture and prevent both micro and macro level instances of embezzlement. Fox (2007) demonstrates the contrast between institutional transparency and aggregate data disclosure, where the latter "does not reveal how institutions actually behave in practice, whether in terms of how they make decisions, or the result of their actions". This opaque form of transparency, such as disclosing only aggregate data on resource revenues, is not an adequate method to curb corruption in extractive industries.

Other attempts to measure the impact of transparency on governance assert that transparency's positive effect on corruption is conditioned by specific factors, such as publicity, education and accountability (Kolstad \& Wiig, 2009, p. 529). Transparency works to improve management of oil revenues when politicians are accountable and civil society groups can function as whistle blowers. If the information is not disseminated and civil society groups cannot operate, then transparency alone can not alleviate corruption (Lindstedt \& Naurin, 2010). The implications of these studies challenge the work of transparency promoters in non-democratic settings, where there is limited political accountability and public awareness of government policies. The following section discusses transparency advocacy, focusing principally on the EITI process. 


\section{Extractive Industries Transparency Initiative and Corruption}

The revenues from hydrocarbons sometimes surge to very high levels, even as they tend to fluctuate over time. When not monitored carefully, people in positions of power are tempted to misuse these monies. Therefore, despite the alleged theoretical advantages of transparency for development, political elites in resource-rich countries may resist opening up their institutions and surrendering political control over the rents. In such settings, even reformist ministers may face difficulty in adopting economic policies that would harm the interests of few, concentrated beneficiaries. In addition, many resourcerich developing countries might actually lack the mechanisms required to ensure resource revenue transparency (Atkinson \& Hamilton, 2003).

When there is limited domestic initiative and capacity for change, external influences, such as World Bank and International Monetary Fund, acquire significance in facilitating reforms. Developing energy-exporting states attract particular interest from these institutions due to their vital importance for the global economy. Transparency in natural resource revenues is also promoted by global advocacy groups, such as Revenue Watch and Publish What You Pay, as a measure to prevent corruption and mismanagement of revenues. External factors thus offer incentives and/or apply pressure to producer states to initiate governance reforms. In the last decade, the Extractive Industries Transparency Initiative (EITI) has been the most successful among those influences (Del Castillo, 2009; Ernst, 2013) and it merits a detailed focus.

The EITI is a coalition of countries, companies, and civil society groups that aims to establish global standards of transparency in extractive industries. The stakeholders of 
the EITI include the governments of the United Kingdom, Germany, Qatar, the United States; companies such as the BP and ExxonMobil; and global advocacy networks such as Revenue Watch. The initiative also closely cooperates with the World Bank and the International Monetary Fund. The membership of the EITI increased very rapidly since it was launched in 2003, following the international support received from the United Kingdom and the World Bank. This is a major achievement for an international organization, which accepts members on a voluntary basis. As of November 2015, 49 resource-rich countries implement the EITI standard and 31 countries are fully compliant to the initiative. ${ }^{1}$

What kind of transparency does the EITI advocate? The complexity of the resource management process makes it difficult to define transparency in the extractive industries. Transparency in this sector may refer to the public availability of information on revenues, expenditures, awarding of contracts and licenses, public procurement, politicians' personal wealth, appointments and promotions, clarity of roles and responsibilities, adequacy of internal and external accounting, auditing, and open budget processes (IMF, 2007; Kolstad \& Wiig, 2009, p. 526). Despite this multifaceted nature of transparency in the extractive industries, the EITI's initial approach to transparency focused only on government revenues from the sale of hydrocarbons and minerals. In that sense, the initiative originally adopted the third aspect of transparency - as aggregate data disclosure.

\footnotetext{
${ }^{1}$ EITI compliant countries as of November 2015: Albania, Burkina Faso, Cameroon, Central African Republic, Chad, Côte d'Ivoire, Democratic Republic of Congo, Ghana, Guatemala, Guinea, Indonesia, Iraq, Kazakhstan, Kyrgyz Republic, Liberia, Mali, Mauritania, Mongolia, Mozambique, Niger, Nigeria, Norway, Peru, Republic of the Congo, Sierra Leone, Tanzania, Timor-Leste, Togo, Trinidad and Tobago, Yemen, Zambia.
} 
Accordingly, in the EITI model, participating oil, gas, and mining companies publish what they pay to the governments of their host countries, the governments publish what they receive. In this manner, the EITI process provides reliable information on resource revenues. A country becomes a candidate when the leader of the state makes a decisive declaration on country's commitment, assigns an executive director to oversee the process, and establishes a multi-stakeholder group. This group includes designated representatives from the government, companies, and civil society groups (Eigen, 2006). Candidate status is only temporary and candidate countries have to start the validation process within two and a half years. The validation process is an "external, independent evaluation mechanism", which determines whether or not a country met all the requirements to be compliant (EITI, 2013b). The requirements for compliance are effective oversight by the multi-stakeholder group, timely publication of comprehensive and easily accessible EITI reports that reveal government's income from the extractive industries, and a credible assurance process. Once countries are validated, the EITI Board designates them the complaint status. The validation process continues after compliance and EITI complaint countries go through mandatory validation every three years.

The proponents of the EITI share the implicit assumption that membership and compliance will lead to higher levels of transparency, which will eventually curb corruption. The official EITI view is that transparent revenues will instigate anticorruption reforms and improve trust and stability in the extractive industries (EITI, 2014). The EITI directors are confident in their institution's ability to enable other actors 
(NGOs and independent researchers) to evaluate the validity of the published revenues and to observe whether or not these proceeds were well spent. ${ }^{2}$

Before 2013 the EITI process focused almost exclusively on aggregate disclosure of government revenues and omitted institutional aspects of transparency such as signing of contracts with international oil companies, public expenditures, and investments for sustainable development. In response to an evaluation report in 2011, which underlined various problems with this approach (Scanteam, 2011), the EITI standard was revised in 2013. The new EITI standard now includes additional disclosure requirements for stateowned companies, transit payments, and social expenditures in addition to disaggregated reporting and improved auditing mechanisms. The new standard also encourages disclosure of production contracts though this is not a mandatory requirement to become compliant (EITI, 2013a). A full evaluation of the new standard would be premature at this moment. Nevertheless, the impact is likely to be positive because the changes underline a shift towards a more institutional understanding of transparency, which can better address corruption.

A number of comparative studies on the EITI focus on the process itself and analyze how the initiative operates in different countries (Aaronson, 2011). Similarly, reports by international observers, such as Revenue Watch, point out to the challenges the initiative faces in broad terms, and provide suggestions on how the EITI should move beyond its mandate (Dykstra, 2011). These are also numerous case studies and reports that identify challenges the EITI faces in different political and social contexts (Keblusek,

\footnotetext{
${ }^{2}$ Interview with Dr. Francisco Paris, EITI Regional Director, 10 May 2011, Oslo.
} 
2010). To the best of this author's knowledge, only three studies systematically analyze the impact of EITI membership on transparency or corruption (Corrigan, 2014; DavidBarrett \& Okamura, 2013; Ölcer, 2009). Ölcer (2009) finds that EITI membership does not have a significant impact on corruption levels. However, her research only focuses on the period between 2002 and 2007. Since almost all EITI-affiliated countries became candidates after 2007, the results are likely to be premature. Interestingly, two recent studies have conflicting results on the relationship between EITI membership and corruption. Based on panel data analysis, Corrigan (2014) finds that EITI membership does not improve corruption levels. In contrast, by using a matched pairs design, DavidBarrett and Okamura (2013) argue that corruption levels decline after EITI membership. Regardless of their conclusions, neither study offers a detailed theoretical explanation of why and how transparency is implemented in member countries. As many endorsers of the EITI assume that transparency and corruption are negatively correlated, it is crucial to analyze the theoretical implications of EITI compliance.

\section{Evaluating the pre-2013 EITI: Mock Compliance?}

The theoretical framework of the relationship between EITI membership, transparency, and corruption is best captured by the compliance literature, which explains how external influences may facilitate institutional changes. In many hydrocarbon-rich countries the state enjoys a financial autonomy from the societal forces. As a consequence, promoters of global norms focus their efforts on the political elite, which have the main authority to initiate reforms. 
The compliance literature asserts that both material and ideational factors may contribute to leaders' decisions to either comply or defect. These factors correspond to the logics of consequences and appropriateness respectively (March \& Olsen, 1984). These two logics are not mutually exclusive and they may both have an impact on compliance during different stages of the process. However, given the strategic importance of natural resources, I expect the logic of consequences to be more relevant for the EITI process, especially in short and medium terms (Walter, 2008). In this logic, leaders evaluate immediate benefits and costs of carrying out transparency reforms and they comply with the demands of external transparency promoters when complying provides additional opportunities for the political elite to maintain their privileged status in an economy dominated by energy revenues. Ideational factors, which include social learning and internalization of norms by the help of epistemic communities (Finnemore \& Sikkink, 1998; Haas, 1992), are also essential; yet they are more likely to be effective in a substantially longer time frame (Walter, 2008, p. 35).

I expect, then, the leaders to be more open to transparency in extractive industries when the benefits of compliance outweigh the costs. Yet, these cost-benefit calculations may be complicated by many factors. Especially when the external pressure for reform is strong and the costs of compliance are high, countries might be tempted to seek alternatives to full compliance. One such alternative is mock compliance, which is a term coined by Andrew Walter in response to various financial reforms adopted by countries in East Asia (2008). Mock compliance is a rational process, which attempts to appease international audience by mimicking compliance to global norms. It combines the 
"rhetoric and outward appearance of compliance with international standards together with relatively hidden behavioral divergence from such standards" (Walter, 2008, p. 5).

Mock compliance underlines a decoupling, which explains the gap between institutionalized policies and substantive outcomes (Meyer \& Rowan, 1977). At the international level, decoupling often occurs in response to external pressures, which demand compliance with regulations and norms on good governance (Tilcsik, 2010, p. 1474). States that are eager to signal compliance, albeit only symbolically, sign on to initiatives without necessarily changing their actual policy practices. Therefore, decoupling helps countries to gain legitimacy while maintaining the internal flexibility to pursue their goals (Meyer \& Rowan, 1977).

Mock compliance is a compromise for many governments, who are not willing to fully implement certain best practices promoted by IFIs and global advocacy networks. Andrew Walter states three conditions for mock compliance strategies to be viable: high costs of private sector compliance, high costs of noncompliance, and high costs of third party compliance monitoring $(2008$, p. 36). Compliance to the norm of transparency in resource management satisfies all three criteria. Firstly, for many resource-rich countries, embedded interests in the extractive industries and clientelism present a major domestic obstacle to transparency and anti-corruption reforms. Complete institutional transparency and free media may reveal severe mismanagement of revenues and corruption in extractive industries (Mehlum et al., 2008). As a consequence, the costs of making resource management entirely transparent would be too high for those who benefit the most from secret financial transactions, bribes, embezzlement, etc. 
Secondly, it is evident that transparency has become a globally accepted norm with the EITI being the main promoter of this norm in the extractive industries. Substantial material benefits and reputational gains associated with compliance can make the costs of shunning the EITI too high for resource-rich countries. What are the immediate benefits of compliance? In theory, implementing transparency in the resource sector signals a political will to embrace open markets and good governance, which could lead to substantial benefits for non-hegemonic countries by improving their creditworthiness in the realm of global finance (Simmons, 2001; Walter, 2008, p. 39). In addition, a potential benefit of adopting transparency in the management of natural resources is the increased likelihood of attracting foreign investment in the extractive industries. Globalization of capital demands that countries compete with each other in order to host foreign investment. For countries that rely on extractive industries to earn foreign exchange, this competition to attract foreign direct investment (FDI) is especially important because resource sectors often require long-term, capital-intensive investments from multinational companies to maintain production levels (De Soysa \& Oneal, 1999). In this context, the competition to lure and maintain FDI, especially from industrialized democracies, increases leadership incentives to adopt norms such as transparency (Henisz, 2002; Walter, 2008, p. 40).

Finally, third party costs of monitoring of transparency and corruption in all stages of resource management are quite high due to the complexity of the value chain in extractive industries. In addition, the EITI relies on mechanisms that function well in industrialized democracies, yet may be problematic for many developing countries. For instance, the EITI model requires that civil society have capacity and freedom to raise 
concerns about the process and act as whistle blowers. Furthermore, it demands an institutional system, which would allow politicians and firms to be accountable for any discrepancies discovered. ${ }^{3}$ However, in many resource-rich states civil societies are financially weak and they lack the capacity to monitor revenues. Furthermore, especially in authoritarian countries, NGOs are unable to hold politicians or businesses accountable for corruption or mismanagement of revenues.

In light of these considerations, it is clear that the pre-2013 EITI experience carried all the pre-conditions of mock compliance, especially given the fact that the ultimate aim of these efforts was to curb corruption and mismanagement. While the EITI members did not directly deceive the global community, the narrow vision of transparency they adopted caused a major decoupling of institutionalized policies and substantive outcomes. Before 2013, the EITI process focused mostly on aggregate data on revenues, which was fairly limited given the whole range of economic activities associated with resource management. This was a snapshot picture, attacking only the middle of the value chain. ${ }^{4}$ This narrow interpretation was relatively easier to implement since it did not threaten patronage relations, ownership systems, and off-the-books corruption at the highest levels. It could also bring major financial benefits to the implementing countries without any significant political costs. In these circumstances, political leadership encouraged transparency reforms to the extent necessary to gain favorable international publicity and investment flows.

\footnotetext{
${ }^{3}$ Interview with Dr. Francisco Paris, EITI Regional Director, 10 May 2011, Oslo.

${ }^{4}$ Interview with Dr. Francisco Paris, EITI Regional Director, 10 May 2011, Oslo.
} 
Revenue transparency by itself is a novel endeavor to pursue for resource-rich countries and it is likely to make a positive impact on overall governance. Yet, the effectiveness of this method for curbing corruption is questionable. As mentioned in the previous sections, corruption can take place in various stages of the resource management process. The evidence from resource-rich countries shows that corrupt practices may occur as early as the negotiations and the contract phase, which is not covered by the EITI process (Kolstad \& Wiig, 2009, p. 528). For example, the EITI may publish that a mining company in Lima is paying 3.7 billion dollars for royalties, but "it does not say anything because we do not know if this is what they are supposed to pay." ${ }^{5}$ In fact, without the contracts and the books of the company, there is no process to establish the exact debt. Besides contracts, corruption is also very likely to happen at the spending stage. Public expenditures have a crucial role in sustaining patronage politics in resourcerich countries and again this was not in the agenda of the original EITI standard (Kolstad \& Wiig, 2009, p. 529; Öge, 2014). This set-up encouraged member governments to embrace the EITI without any clear intention to tackle corruption. For this reason, despite the popularity and the apparent success of transparency efforts associated with the EITI, I do not anticipate a positive change in perceptions of corruption in the period between 2006 and 2013.

\footnotetext{
${ }^{5}$ Interview with Dr. Francisco Paris, EITI Regional Director, 10 May 2011, Oslo.
} 


\section{Interrupted Time Series Design}

This paper problematizes the basic premise of the EITI process prior to 2013, which implicitly assumed that the initiative would increase overall transparency and this would eventually phase out corruption. As mentioned above, the literature on transparency is unable to provide a definite answer on its alleged positive impact on corruption. It is shown that transparency is more likely to contribute to better governance when it is coupled with mechanisms of free speech and political accountability. However, it is not clear whether it can fulfill this goal in non-democratic environments. Furthermore, despite the expectations of EITI supporters, so far there is no empirical evidence to demonstrate that visibility of resource revenues is positively correlated with overall transparency and negatively correlated with corruption. In fact, studies demonstrate that some early adopters of EITI have seen their corruption levels deteriorate over the years (Öge, 2014).

To evaluate how EITI membership affected transparency and perceptions of corruption before 2013, I use an interrupted time-series (ITS) design, which can analyze the causal impact of an intervention (Lewis-Beck \& Alford, 1980; Linden, 2015). The analysis compares observations on either side of a cut-off point in order to detect any apparent changes in the dependent variable initiated by the intervention. In this case, the cut-off point is the first year of EITI membership. However, since the actual year of membership varies for each country it would be difficult to test the impact of EITI on transparency and corruption across cases. To resolve this issue, I create the variable, TIME, which is a running count of integers. The variable takes the value " 1 " the year a 
country becomes a member and increases by one every year. The count also goes backwards in order to capture trends in transparency and corruption before membership. For all countries the value of TIME the year before membership would be " 0 ", two years before membership would be "-1", etc. Table 1 illustrates the changing values of TIME for three EITI members. Accordingly, Azerbaijan became an EITI candidate and member in 2007, Indonesia in 2010, and Zambia in 2009. Defined as such, TIME allows us to observe any significant changes in governance trends, or interruptions, in countries before and after EITI membership.

Table 1 Values of TIME for selected EITI members

\begin{tabular}{|l|c|c|c|c|c|c|c|c|}
\hline Country & 2006 & 2007 & 2008 & 2009 & 2010 & 2011 & 2012 & 2013 \\
\hline Azerbaijan & 0 & 1 & 2 & 3 & 4 & 5 & 6 & 7 \\
\hline Indonesia & -3 & -2 & -1 & 0 & 1 & 2 & 3 & 4 \\
\hline Zambia & -2 & -1 & 0 & 1 & 2 & 3 & 4 & 5 \\
\hline
\end{tabular}

The first analysis focuses on the impact of EITI membership on transparency levels. As mentioned in the literature review, it is difficult to find an indicator for transparency that can capture its different aspects. However, since the pre-2013 EITI focused exclusively on aggregate data disclosure, we can narrow our treatment of transparency accordingly here. To measure this aspect of transparency, this research uses the HRV index, which looks at collection and dissemination of data by governments. Specifically, using a Bayesian Item Response Theory, the HRV index focuses on governments' reporting of credible aggregate economic data to World Bank's World 
Development Indicators. The index covers 125 countries from 1980 to 2010 and analyzes 240 economic variables including production and trade in extractive industries. The Item Response Method examines missing data among these variables and treats transparency as a latent term, which highlights governments' tendencies to disclose. Overall, governments that provide more data are likely to have higher HRV scores. However, this method also allows different weights for different types of data reported based on "how many other countries actually reported data on the measure, and how much a country distinguishes itself from other countries by reporting data on a given measure" (Hollyer et al., 2014a).

The HRV index captures a reliable and an objective measure of a government's capacity and intent to disclose even if it does not quite capture institutional and media related aspects of transparency. Another major advantage of this index is that unlike many indices of governance it is not based on subjective views of experts, but rather on objective criteria. Even though the index is relatively new, it has already featured in several works in the literature as a measure of economic transparency (Graham, Johnston, \& Kingsley, 2015; Hollyer, Rosendorff, \& Vreeland, 2014b, 2015; Michener, 2015; Rosendorff \& Shin, 2012) and inspired more specialized indexes (Copelovitch, Gandrud, \& Hallerberg, 2015; Williams, 2015). This present research will be the first to use the HRV index in order to measure the impact of EITI membership on overall transparency levels.

As the last available year of the HRV index is 2010, the analysis here does not include countries that joined the EITI after 2010. The regression equation for this ITS is expressed as follows (Linden \& Adams, 2011; Simonton, 1977): 


$$
\text { Transparency } \mathrm{t}_{\mathrm{t}}=\beta_{0}+\beta_{1} T_{I M E_{\mathrm{t}}}+\beta_{2} M E M B E R_{\mathrm{t}}+\beta_{3} T I M E_{\mathrm{t}} M E M B E R_{\mathrm{t}}+\varepsilon_{\mathrm{t}}
$$

Transparency is the dependent variable, which is indicated by the HRV index. TIME is a running count of integers as explained above. MEMBER is a dummy variable, which takes the value 1 if a country is an EITI member in a given year and 0 if a country is not yet a member. The model also includes an interaction of TIME and MEMBER. The coefficient for MEMBER $\left(\beta_{2}\right)$ indicates change in transparency levels immediately after the intervention. The coefficient of the interaction variable $\left(\beta_{3}\right)$ represents the difference in the slope of the outcome variable before and after the intervention, hence reflects longer-term trends. Table 2 shows the outcome of the OLS-regression based on the ITS model. The results show that all variables are actually significant. EITI membership has an immediate positive impact on transparency. Furthermore, the slopes of outcome variable over time are significantly different before and after membership. These results imply that candidacy and membership to the EITI actually improves overall transparency defined as disclosure of aggregate economic data. Finally, the negative value of TIME shows that there is a declining trend in transparency levels among EITI countries. 
Table 2 - Interrupted Time Series Analysis -EITI Membership and Transparency

\begin{tabular}{ll}
\hline Variable & \\
\hline TIME & $\begin{array}{l}-0.294^{* * *} \\
(-8.52)\end{array}$ \\
& $0.223^{*}$ \\
MEMBER & $(-2.09)$ \\
& $0.128^{*}$ \\
INTERACTION & $(-2.49)$ \\
& 0.204 \\
COns & -0.77 \\
\hline & 170 \\
\hline
\end{tabular}

$\mathrm{t}$ statistics in parentheses

$* \mathrm{p}<0.05, * * \mathrm{p}<0.01, * * * \mathrm{p}<0.001$

The graphical presentation is often best way to show whether or not a discontinuity exists at the cutoff point. Accordingly, Figure 1 demonstrates the relationship between the outcome and the rating variable for all EITI members with the cut-off point marked as the year of membership. The variable of TIME allows us to visualize the impacts of EITI affiliation for all these countries as if they all became members in the same year. The graph shows that the EITI membership moderates the overall negative trend in transparency levels. 


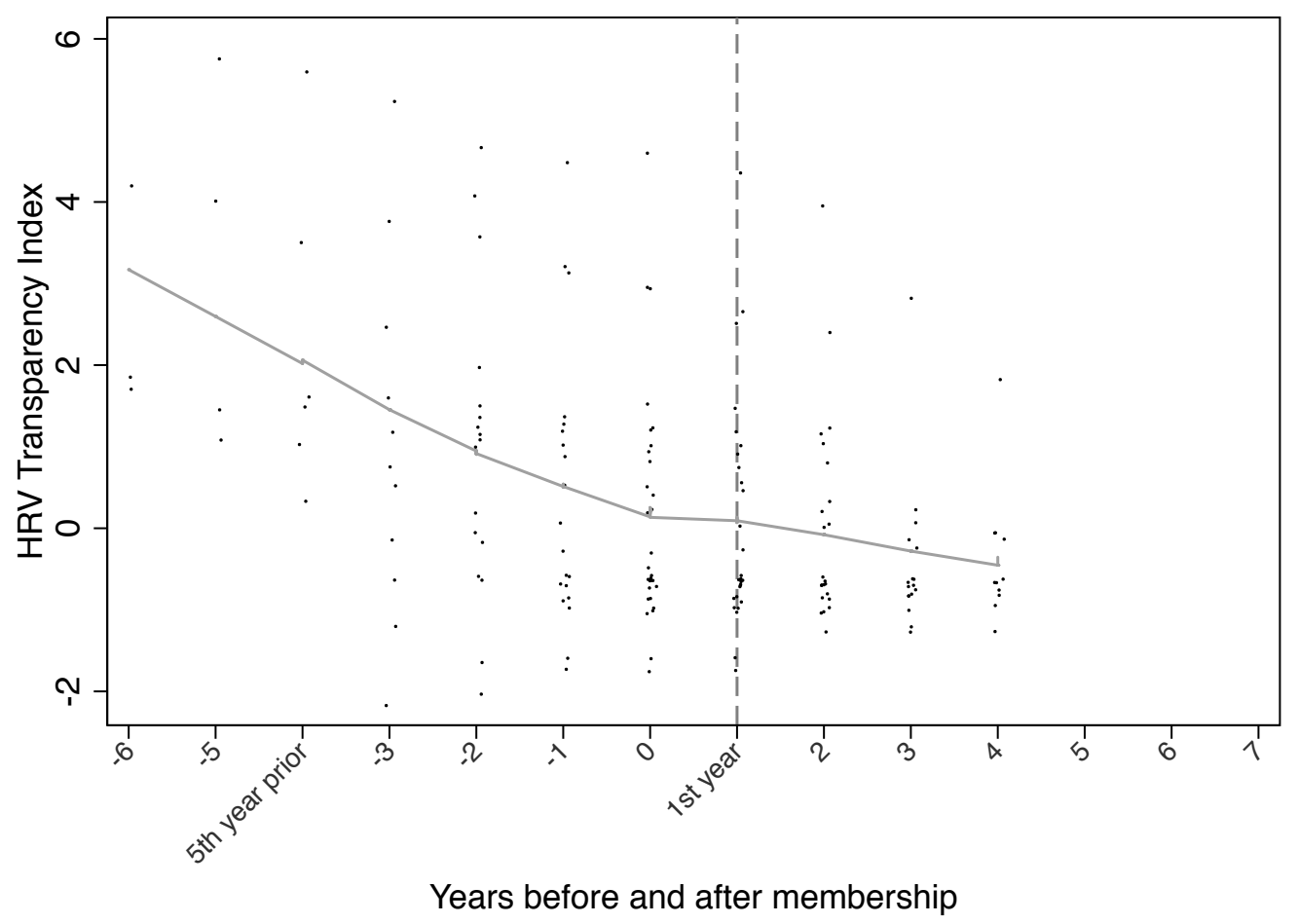

Figure 1 - Impact of EITI on Transparency Levels

Data Source: (Hollyer et al., 2014a)

Normally, a control group of non-EITI members could be used to provide additional validity to the analysis above. However, since membership date among EITI countries is not uniform, including a control group of non-EITI members in the regression analysis is not possible. Instead, the Figure 2 shows the HRV index in 43 nonEITI resource-rich countries between 2006 and 2010. The graph shows that transparency levels also declined for this group during this period and there was not an apparent external shock. 


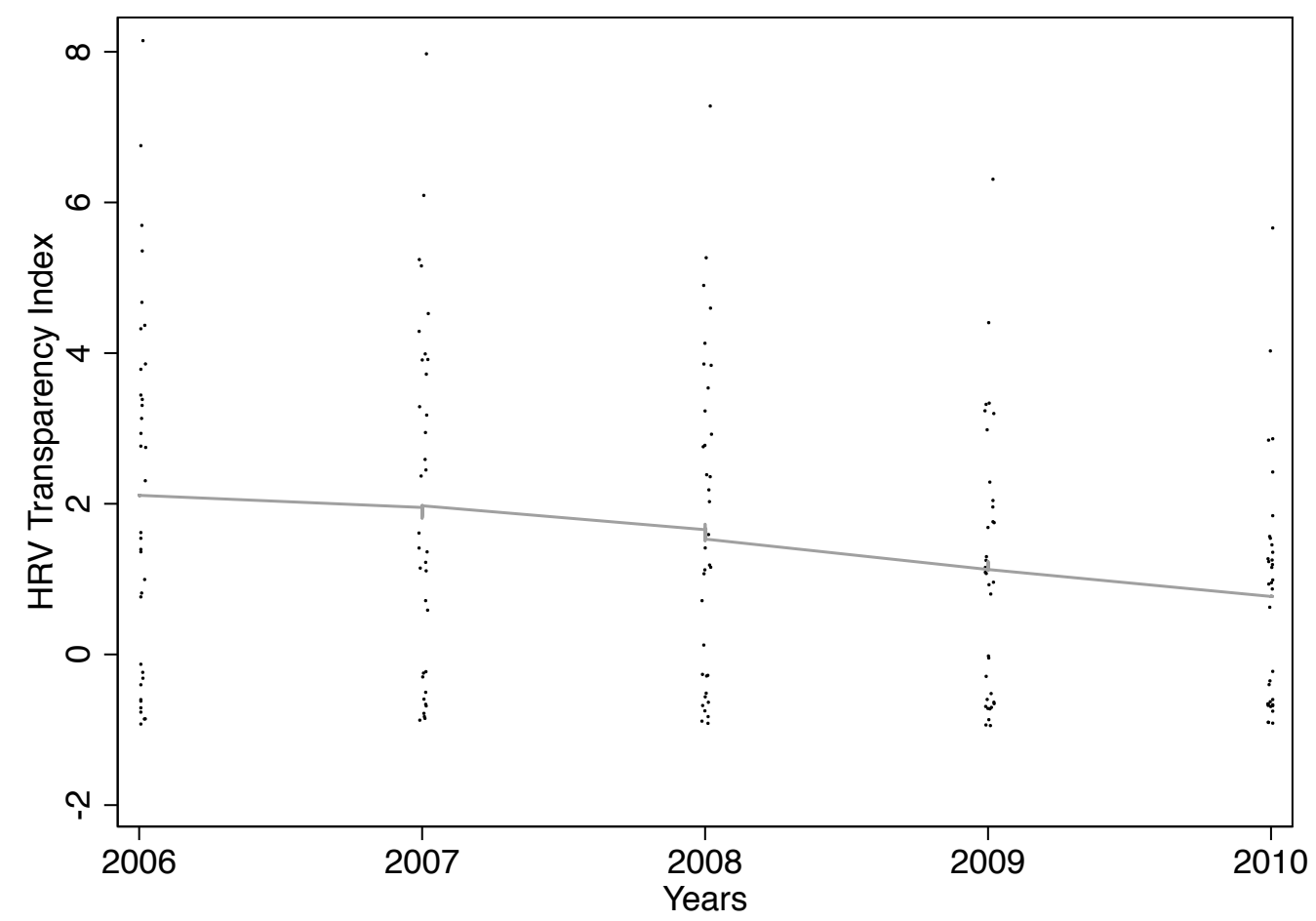

Figure 2 - Transparency Levels in Non-EITI Resource-Rich Countries

Data Source: (Hollyer et al., 2014a)

The second analysis measures the impact of EITI membership on perceptions of corruption. The universe of cases includes EITI members as of September 2013. The time frame is set between 2006 and 2013 and captures the membership dates of all current EITI members except Myanmar, Seychelles, the United Kingdom, the United States and Papua New Guinea, which became members in 2014. The dependent variable is control of corruption (World Bank, 2013), a continuous index from -2.5 to 2.5 with higher scores associated with lower levels of corruption. The index is based on surveys of experts and entrepreneurs, which comment on the nature of transactions between individuals, governments, and businesses. As a composite index, control of corruption is subject to 
various criticisms such as lack of comparability over time and space, or embedded hidden biases from the perspective of business elites. Yet, in the absence of a better alternative, this index serves as one of the best indicators of corruption in the governance literature (Kaufmann, Kraay, \& Mastruzzi, 2007).

The index does not measure corruption specific to the extractive industries; unfortunately, this type of quantitative data does not exist. Nevertheless, in many EITI countries, foreign experts and entrepreneurs that complete corruption surveys almost exclusively operate in these industries. Furthermore, as a recent OECD report suggests, the extractive industries has more foreign bribery cases than any other sector (OECD, 2014). The resource sector is more susceptible to corruption since it generates substantial amounts of revenues in short periods of time, which can easily be channeled to third parties. For these reasons, it is quite likely that for many resource-rich countries, corruption in the extractive industries would be the most important determinant of this index. In other words, the respondents' perceptions of corruption would largely reflect corruption levels in the extractive industries. Finally, the above analysis reveals that EITI's positive impact on transparency is not exclusive to the extractive industries. EITI membership has an immediate impact on overall aggregate data disclosure. Hence, measuring its impact on general perceptions of corruption would not be a huge leap. The regression equation for this ITS is as follows:

$$
C O R_{\mathrm{t}}=\beta_{0}+\beta_{1} T I M E_{\mathrm{t}}+\beta_{2} M E M B E R_{\mathrm{t}}+\beta_{3} T I M E_{\mathrm{t}} M E M B E R_{\mathrm{t}}+\varepsilon_{\mathrm{t}}
$$

Table 3 shows the outcome of the OLS-regression based on the ITS model. As expected, none of the variables are significant, which implies that EITI candidacy does 
not have a distinct impact on corruption levels. The results do not change when an alternative indicator of corruption from the International Country Risk Guide is used (PRS, 2014).

Table 3 - Interrupted Time Series Analysis - EITI Membership and Corruption

\begin{tabular}{|c|c|}
\hline Variable & \\
\hline TIME & $\begin{array}{l}-0.00728 \\
(-1.12)\end{array}$ \\
\hline MEMBER & $\begin{array}{l}0.0551 \\
-0.7\end{array}$ \\
\hline INTERACTION & $\begin{array}{l}-0.00163 \\
(-0.22)\end{array}$ \\
\hline _cons & $\begin{array}{l}-0.665^{* * *} \\
(-6.43) \\
\end{array}$ \\
\hline $\mathbf{N}$ & 345 \\
\hline
\end{tabular}

A potential concern with this result is that EITI membership, or candidacy, does not necessarily signify full compliance. In fact, many members become fully compliant only two years after having become candidates. To address this issue, the regression equation in Table 4 replaces the variable MEMBER with COMPLIANT, which is a lagged measure of membership by two years. The results, however, are very similar. Full compliance to the initiative in this period does not seem to have an impact on perceptions of corruption. 
Table 4 - Interrupted Time Series Analysis - EITI Compliance and Corruption

\begin{tabular}{ll}
\hline Variable & \\
\hline TIME & $\begin{array}{l}-0.000554 \\
(-0.12)\end{array}$ \\
& 0.0925 \\
MEMBER & $(-0.76)$ \\
& \\
INTERACTION & -0.00743 \\
& $(-0.83)$ \\
& $-0.715^{* * *}$ \\
Cons & $(-7.34)$ \\
\hline & 345 \\
\hline
\end{tabular}

$\mathrm{t}$ statistics in parentheses

$* \mathrm{p}<0.05, * * \mathrm{p}<0.01, * * * \mathrm{p}<0.001$

The graph in Figure 3 demonstrates the relationship between corruption and TIME for all EITI members with two cut-off points: first and third years of membership. The regression analysis and the graph confirm the initial hypothesis of the paper regarding EITI membership and corruption in this period. Compliance to the pre-2013 standard does not affect perceptions of corruption. In addition, we can see that almost all EITI members have already high corruption levels, except for Norway, which is the outlier at the top. 


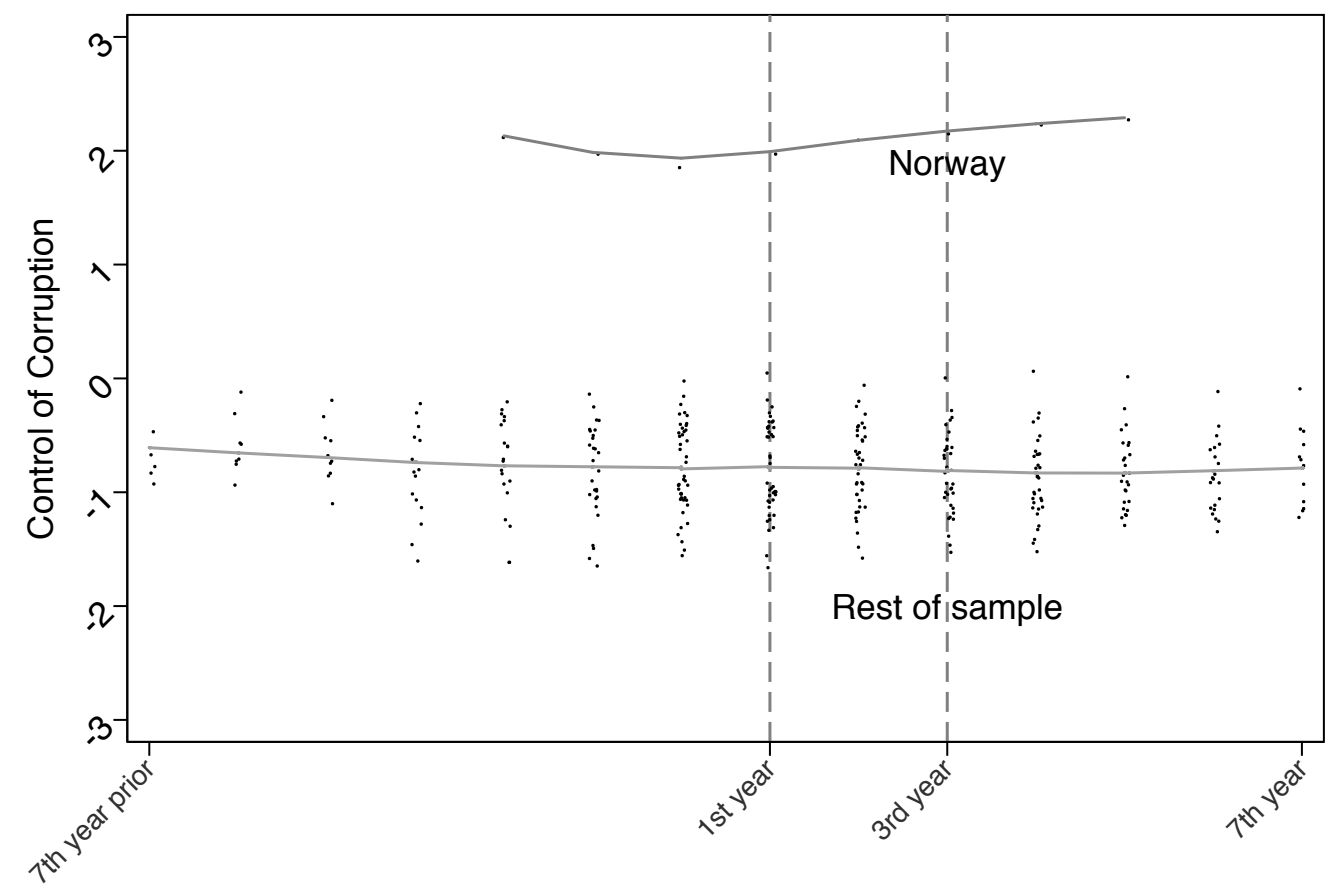

Years before and after membership

Figure 3 - Impact of EITI Membership on Corruption Levels

Data Source: World Bank (2013) Worldwide Governance Indicators

Finally, Figure 4 shows corruption levels in 43 non-EITI resource-rich countries during the same time period. Trends in corruption levels in this control group do not show any divergence from those of EITI members. Furthermore, the figure reveals that there was no major external shock in this period that could have distorted the results. 


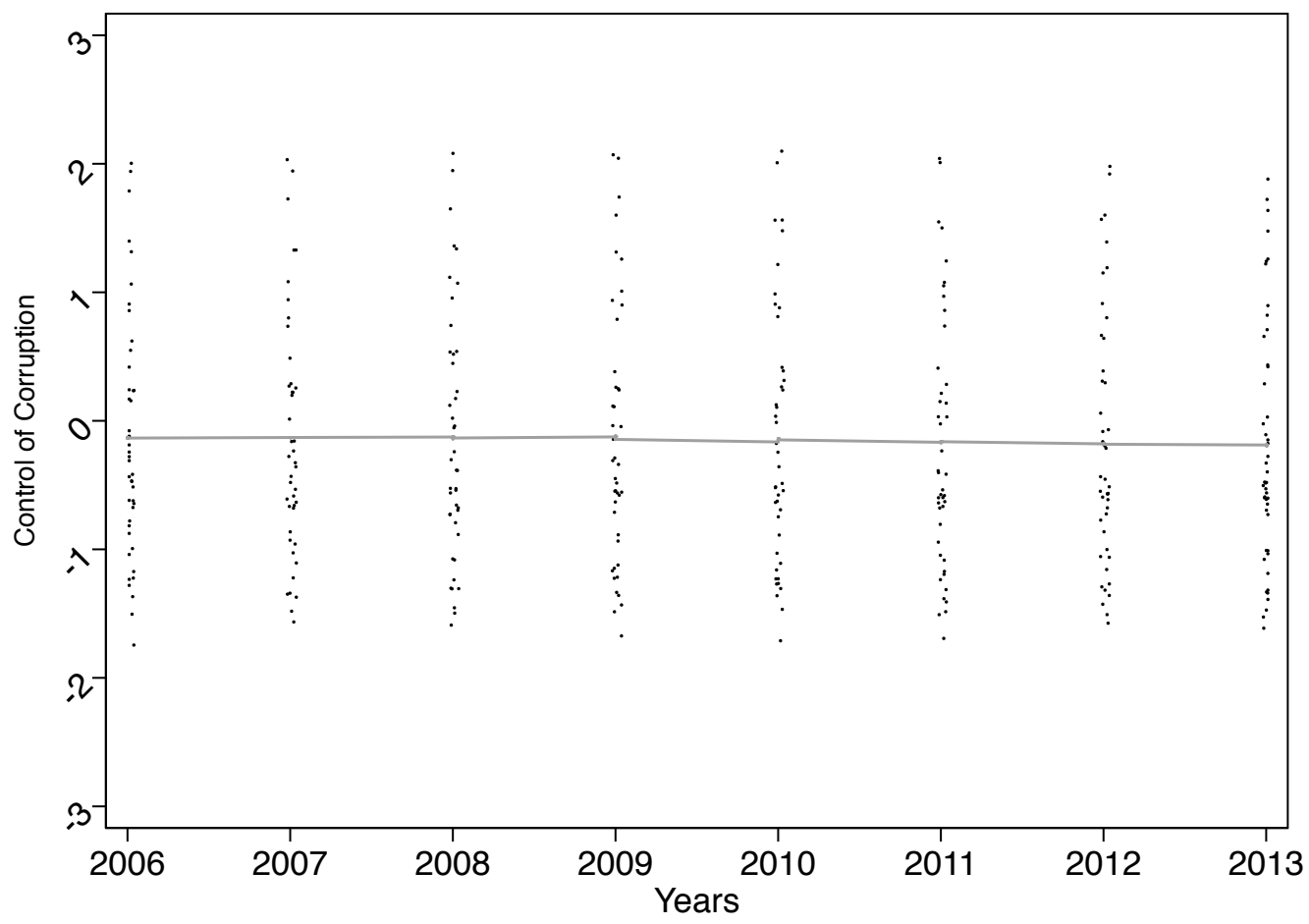

Figure 4 - Corruption Levels in 43 Non-EITI Resource-Rich Countries

Data Source: World Bank (2013) Worldwide Governance Indicators

\section{Panel Data Analysis and Results}

In addition to the ITS model above, a panel data analysis can offer a comprehensive method of understanding medium-term trends in transparency and corruption levels. The analysis focuses on the relationship between EITI membership, transparency and perception of corruption, and it provides additional verification of the results in the previous section. The first analysis focuses on the impact of EITI membership on the HRV index. Hence, transparency is the dependent variable and the annual data covers the period from when countries officially began to be accepted as EITI candidates up to 2010, the last available year for the HRV index. 
The main independent variable is EITI membership. EITI is a dichotomous variable, which takes the values 0 and 1 based on country's membership status with the initiative. The variable YEAR is included in the model as an explanatory variable to control for any existing trends in transparency levels, which are independent of EITI membership. I also introduce two other variables as potential determinants of transparency. Firstly, transparency and corruption in the extractive industries are closely related to the functioning of national bureaucracies (Brunetti \& Weder, 2003). Therefore, I use the index of Bureaucratic Quality from International Country Risk Guide (ICRG) as an explanatory variable, which runs from 0 to 4 . Another potential key variable is the level of democracy (Brunetti \& Weder, 2003; Lindstedt \& Naurin, 2010). I expect higher levels of democracy to be correlated with higher levels of transparency and lower levels of corruption thanks to higher political accountability and public monitoring of finances. I use the Polity IV dataset to measure democracy, which runs from -10 to 10 , with higher values associated with more democratic institutions. Finally I also use logged GDP per capita (World Bank, 2014) and the Freedom of the Press index by the Freedom House (2015) as additional controls.

Since the main purpose of the research is to analyze the impact of variables over time, I carry out a panel data analysis with fixed effects. The fixed-effects model includes country dummies; hence it controls for any time-invariant country characteristics that affect the dependent variable and allows one to assess the net effect of independent variables, which all have 1-year lags, except YEAR. The first model can be specified as follows:

$$
\text { Transparency }_{\mathrm{it}}=\beta_{1} \text { YEAR }_{i(t)}+\beta_{2} \text { EITI }_{i(t-1)}+\beta_{3} B U R_{i(t-1)}+\beta_{4} P O L_{i(t-1)}+\alpha_{\mathrm{i}}+v_{\mathrm{it}}
$$


Table 5 shows the results of the series of panel data regressions with fixed effects.

The standard error estimates are corrected to be robust to disturbances being heteroscedastic. The case selection includes both the universal set of countries (columns 1-2) and those that are considered as resource-rich (columns 3-4). The comprehensive list of all hydrocarbon and mineral-rich countries include 85 countries identified by IMF, Revenue Watch and the EITI (EITI, 2012; IMF, 2010; Revenue Watch, 2013).

Table 5 - Panel Data Analysis - EITI Membership and Transparency

\begin{tabular}{|c|c|c|c|c|}
\hline Variable & (1) All & (2) All & (3) Res & (4) Res \\
\hline YEAR & $\begin{array}{l}-0.378 * * * \\
(-11.40)\end{array}$ & $\begin{array}{l}-0.466 * * * \\
(-10.27)\end{array}$ & $\begin{array}{l}-0.336 * * * \\
(-6.72)\end{array}$ & $\begin{array}{l}-0.399 * * * \\
(-6.03)\end{array}$ \\
\hline EITI & $\begin{array}{l}0.541 * * * \\
(-4.44)\end{array}$ & $\begin{array}{l}0.543^{* * *} \\
(-4.92)\end{array}$ & $\begin{array}{l}0.451^{* *} \\
(-3.07)\end{array}$ & $\begin{array}{l}0.474 * * * \\
(-3.48)\end{array}$ \\
\hline$B U R$ & $\begin{array}{l}0.746^{* *} \\
(-3.29)\end{array}$ & $\begin{array}{l}0.749 * * * \\
(-4.04)\end{array}$ & $\begin{array}{l}0.475^{*} \\
(-2.2)\end{array}$ & $\begin{array}{l}0.562 * * * \\
(-3.52)\end{array}$ \\
\hline POL & $\begin{array}{l}0.00701 * * * \\
(-4.89)\end{array}$ & $\begin{array}{l}-0.0107 \\
(-0.48)\end{array}$ & $\begin{array}{l}0.00653 * * * \\
(-5.31)\end{array}$ & $\begin{array}{l}0.00889 \\
(-0.36)\end{array}$ \\
\hline GDPpc & & $\begin{array}{l}1.338 \\
(-1.22)\end{array}$ & & $\begin{array}{l}0.512 \\
(-0.42)\end{array}$ \\
\hline FOTP & & $\begin{array}{l}-0.019 \\
(-1.80)\end{array}$ & & $\begin{array}{l}-0.0245 \\
(-1.77)\end{array}$ \\
\hline CONS & $\begin{array}{l}758.8^{* * *} \\
(-11.44)\end{array}$ & $\begin{array}{l}924.9 * * * \\
(-10.7)\end{array}$ & $\begin{array}{l}675.3^{* * *} \\
(-6.74)\end{array}$ & $\begin{array}{l}798.5^{* * *} \\
(-6.21)\end{array}$ \\
\hline $\mathbf{N}$ & 555 & 425 & 305 & 240 \\
\hline
\end{tabular}

$\mathrm{t}$ statistics in parentheses

$* \mathrm{p}<0.05, * * \mathrm{p}<0.01, * * * \mathrm{p}<0.001$ 
The results reveal that the EITI membership has a significant and positive impact on the HRV index in all variations of the model. This outcome once again confirms that EITI's efforts to make resource revenues more visible actually transcends to other areas of economic transparency. The negative and significant coefficient of $Y E A R$ underlines the declining trend in the index, which was also already captured by the ITS analysis. Bureaucratic quality has a significant, positive impact on transparency in all the models, whereas the positive impact of democracy ceases to be significant when control variables are introduced. Yet these control variables do not significantly affect transparency levels.

The second panel data analysis focuses on EITI's impact on perceptions of corruption. The only difference from the model above is the dependent variable, which is now control of corruption (2013). For this analysis, annual data covers the period from when countries officially began to be accepted as EITI candidates (2006) up to 2013. The regression model can be specified as follows:

$$
C O R_{\mathrm{it}}=\beta_{1} Y E A R_{i(t)}+\beta_{2} \operatorname{EITI~}_{i(t-1)}+\beta_{3} B U R_{i(t-1)}+\beta_{4} P O L_{i(t-1)}+\alpha_{\mathrm{i}}+v_{\mathrm{it}}
$$

Table 6 shows that the binary EITI variable is not significant in any of the models, once again confirming that EITI membership in this period did not improve perceptions of corruption. YEAR is significant and negative in the first two columns, which highlights the increasing global trend in corruption levels over the years; however, the regression coefficient is very small and this effect disappears when non-resource rich countries are dropped from the analysis. The results also confirm the predictions of the literature on the main causes of corruption. BUR has the expected sign and significant. $P O L$ is also significant and positive in all models. 
Table 6 - Panel Data Analysis - EITI Membership and Corruption

\begin{tabular}{|c|c|c|c|c|}
\hline Variable & (1) All & (2) All & (3) Res & (4) Res \\
\hline YEAR & $\begin{array}{l}-0.00735^{*} \\
(-2.01)\end{array}$ & $\begin{array}{l}-0.0104^{*} \\
(-2.13)\end{array}$ & $\begin{array}{l}-0.00991 \\
(-1.99)\end{array}$ & $\begin{array}{l}-0.0117 \\
(-1.67)\end{array}$ \\
\hline EITI & $\begin{array}{l}-0.0143 \\
(-0.57)\end{array}$ & $\begin{array}{l}-0.0196 \\
(-0.78)\end{array}$ & $\begin{array}{l}-0.0109 \\
(-0.42)\end{array}$ & $\begin{array}{l}-0.0176 \\
(-0.68)\end{array}$ \\
\hline$B U R$ & $\begin{array}{l}0.108 * \\
(-2.37)\end{array}$ & $\begin{array}{l}0.121^{* *} \\
(-2.76)\end{array}$ & $\begin{array}{l}0.121 * * \\
(-2.66)\end{array}$ & $\begin{array}{l}0.104^{*} \\
(-2.2)\end{array}$ \\
\hline POL & $\begin{array}{l}0.00151 * * \\
(-3.05)\end{array}$ & $\begin{array}{l}0.00132 * \\
(-2.18)\end{array}$ & $\begin{array}{l}0.00223^{* *} \\
(-3.26)\end{array}$ & $\begin{array}{l}0.00292 * * * \\
(-5.82)\end{array}$ \\
\hline GDPpc & & $\begin{array}{l}0.0905 \\
(-0.83)\end{array}$ & & $\begin{array}{l}0.0519 \\
(-0.36)\end{array}$ \\
\hline FOTP & & $\begin{array}{l}-0.00289 * \\
(-2.11)\end{array}$ & & $\begin{array}{l}-0.00262 \\
(-1.64)\end{array}$ \\
\hline CONS & $\begin{array}{l}14.45 \\
(-1.97) \\
\end{array}$ & $\begin{array}{l}19.89 * \\
(-2.17)\end{array}$ & $\begin{array}{l}19.33 \\
(-1.93)\end{array}$ & $\begin{array}{l}22.79 \\
(-1.72)\end{array}$ \\
\hline $\mathbf{N}$ & 929 & 749 & 490 & 404 \\
\hline
\end{tabular}

\section{Discussion and Implications}

This research makes an original contribution to show that the EITI process actually leads to more economic transparency in all sectors. However, the results also underline that pre-2013 EITI membership did not have a significant impact on corruption. More precisely, the ITS design and the panel data analysis reveal no discernable change in perceptions of corruption following EITI membership. This outcome contradicts the 
results of a recent study by David-Barrett and Okamura (2013), who claim that EITI members observe a decline in their corruption levels. In the period before 2013, while overall aggregate economic data disclosure increased, critical data on resource management that relates to contracts and spending remained hidden, leaving many corruption networks intact.

An alternative explanation for the endurance of corruption could be that the EITI process is still relatively young and institutions are sticky. It is true that institutional reforms towards better governance may require prolonged periods of adjustment and some members might need additional time to fully reap the alleged benefits of the EITI standard. In other words, even the pre-2013 EITI process might lead to more concrete outcomes as institutions of member countries slowly adapt to new standards of transparency and the political elite internalizes the norm. However, this is certainly a longer-term process than the period defined in this paper. Actually, numerous longerterm members of the EITI, such as Timor-Leste, Azerbaijan, the Republic of Congo, Mali, and Yemen, have actually seen their corruption levels worsen over the last five years (World Bank, 2013).

For the future of transparency promotion and corruption in the extractive industries, the revised EITI standard is certainly a step in the right direction. As mentioned before, the 2013 Standard includes institutional aspects of transparency, which are more likely to confront corruption. To further tackle corruption in extractive industries, governments, civil society groups and businesses could push the current EITI framework to adopt more oversight mechanisms from the parliaments and independent auditing bodies (Dykstra, 2011). This is not an easy task. Many members, such as 
Azerbaijan, are ready to embrace the EITI as long as the process does not alter the distribution of political and economic power in the country. Once a champion of revenue transparency, Baku is finding it increasingly difficult to accommodate civil society input and to comply with the new EITI standards after 2013 (Lomsadze, 2015). In various candidate and compliant countries, the non-governmental organizations are not treated as equal partners and their concerns regarding the process are not adequately taken into account (Öge, 2014). Furthermore, the lack of public awareness and problems of accessibility prevent spillovers to other aspects of governance. The EITI is successful in making revenues more transparent and this impact transcends to other areas of the economy; however, the main problems that are related to the functioning of the bureaucracies and democratization are clearly beyond the mandate of the initiative.

The results have broad implications for the compliance literature. Mock compliance, or decoupling is not unique to the EITI process. This phenomenon is common in international initiatives that attempt to improve existing practices in developing countries. When norms become global and non-compliance becomes too costly, countries often prefer this second-best option (Walter, 2008). For example HafnerBurton and Tsutsui (2005) demonstrate how states use international human right treaties as window dressing while actual practices may continue to deteriorate. Similarly, national environmental policies often decouple from those of global environmental regimes (Schofer \& Hironaka, 2005). Other instances of mock compliance are very blatant. For instance, the decision to invite foreign election observers became a global norm to signal democratization in the last decade. As a consequence, foreign observers monitor almost 80 percent of all national elections, "but puzzlingly, many leaders invite foreign 
observers and orchestrate electoral fraud in front of them" (Hyde, 2011, p. 356). The increasing presence of mock compliance in international treaties and agreements could seriously undermine the efforts to improve governance in developing countries. Hence, further research on the causes and consequences of mock compliance and decoupling is needed.

A second major implication of the results is the importance of democracies in alleviating corruption. As already implicated in the literature on corruption, political accountability and citizen's participation in policy making are key factors in preventing corruption. These aspects of democracies are also likely to improve public monitoring of resource management and limit wasteful spending. In the long run, if and when autocratic resource-rich countries eventually democratize, the already existence of EITI methods could give them a head start to finally address corruption in their extractive industries.

The results also have important policy implications. Transparency promotion as a policy towards developing countries is supported by many industrial states and international organizations. It is often perceived as a key first step towards good governance in resource-rich developing countries. However, if transparency as aggregate data disclosure has no significant effect on corruption, is it still a worthwhile mission? The results suggest that a more comprehensive treatment of transparency that includes its institutional and media-related aspects might be necessary; specifically to distinguish regimes that use transparency reforms for public relations purposes as opposed to genuine reformers. 


\section{Conclusion}

The analysis in this paper shows that association with the EITI between 2006 and 2013 increased overall economic transparency, yet it did not have an impact on perceptions of corruption. While this outcome may seem counterintuitive to many transparency advocates and supporters of the initiative, it is not surprising. Tackling corruption is not an easy task, especially given embedded interests in the production and exportation of natural resources and the complexity of the resource value chain. The lingering corruption in many member states does not suggest that the pre-2013 EITI process was a failure. Though it was not a remedy for corruption, increase in aggregate data transparency in this period provided better information to the general public about the state of the economy, which directly concerns their welfare.

If disclosing revenues is not a practical solution to corruption, what are some viable alternative policies for resource-rich countries? The results suggest that countries would have to improve bureaucratic efficiency and democratic accountability in order to effectively reduce corruption levels. In numerous developing resource-rich countries, national bureaucracies control the resource extraction and management processes through various forms of state-owned companies and sovereign wealth funds. The lack of oversight mechanisms permits unmonitored transfer of funds to accounts and ventures confirmed by the political leadership, which is likely to facilitate corruption. Holding these national bureaucracies on the extractive industries to higher standards of corporate conduct and improving how they are governed could help restrain the rentier mentality and control corruption. 
Acknowledgements: I would like to thank Juliet Johnson and Marc André Bodet for their valuable suggestions on earlier versions of this paper. 


\section{Bibliography}

Aaronson, Susan Ariel. (2011). Limited partnership: Business, government, civil society, and the public in the Extractive Industries Transparency Initiative (EITI). Public Administration and Development, 31(1), 50-63.

Atkinson, G, \& Hamilton, K. (2003). Savings, growth and the resource curse hypothesis. World Development, 31(11), 1793-1807.

Beblawi, Hazem. (1987). The Rentier State in the Arab World. In H. Beblawi \& G. Luciani (Eds.), The rentier state (pp. 49-62). New York: Croom Helm.

Berliner, Daniel. (2014). The political origins of transparency. The Journal of Politics, 76(02), 479-491.

Bohr, Annette. (2003). Independent Turkmenistan: from post-communism to sultanism. In S. N. Cummings (Ed.), Oil, Transition and Security in Central Asia (pp. 9-24). London: Routledge.

Broz, J. Lawrence. (2002). Political system transparency and monetary commitment regimes. International Organization, 56(04), 861-887.

Brunetti, Aymo, \& Weder, Beatrice. (2003). A free press is bad news for corruption. Journal of Public economics, 87(7), 1801-1824.

Chortareas, Georgios, Stasavage, David, \& Sterne, Gabriel. (2002). Does it pay to be transparent? International evidence from central bank forecasts. Review - Federal Reserve Bank of Saint Louis, 84(4), 99-118.

Copelovitch, Mark, Gandrud, Christopher, \& Hallerberg, Mark. (2015). Financial Regulatory Transparency, International Institutions, and Borrowing Costs. Paper presented at the The Political Economy of International Organizations Annual Conference, University of Utah, Salt Lake City, Utah. http://wp.peio.me/wpcontent/uploads/PEIO8/Copelovitch, Gandrud, Hallerberg 3.2.2015.pdf

Corrigan, Caitlin C. (2014). Breaking the resource curse: Transparency in the natural resource sector and the extractive industries transparency initiative. Resources Policy, 40, 17-30.

Dahl, Robert Allen. (1971). Polyarchy: Participation and opposition. New Haven: Yale University Press.

David-Barrett, Liz, \& Okamura, Ken. (2013). The transparency paradox: why do corrupt countries join EITI. ERCAS, Working Paper No.38.

De Soysa, Indra, \& Oneal, John R. (1999). Boon or bane? Reassessing the productivity of foreign direct investment. American Sociological Review, 766-782.

Deese, David A. (2003). From Executive Crafting to Pluralistic Politics: Political and Economic Reform as Sequential, Cumulative Processes in Developing States. In S. Ramaswamy \& J. Cason (Eds.), Development and Democracy: New Perspectives on an Old Debate (pp. 43-68). Hanover: University Press of New England.

Del Castillo, Graciana. (2009). Helping Africa in the Fight Against Corruption. Retrieved 03/31, 2016, from http://www.nytimes.com/2009/06/13/opinion/113africa.html? r=1

Dykstra, Page. (2011). EITI 2011 : Learning from Success and Challenges. Revenue Watch Retrieved 01/12, 2016, from 
http://www.resourcegovernance.org/sites/default/files/EITI lessons 2011-0223.pdf

Eigen, Peter. (2006). Fighting corruption in a global economy: Transparency initiatives in the oil and gas industry. Houston Journal of International Law, 29(2), 327-354.

EITI. (2012). EITI Countries. Retrieved 09.03, 2012, from http://eiti.org/countries/reports/compare/2673\%2C2004

EITI. (2013a). The EITI standard. Retrieved 03/15, 2014, from http://eiti.org/files/English EITI STANDARD 11July 0.pdf

EITI. (2013b). EITI Validation. Retrieved 12/15, 2014, from https://eiti.org/validation

EITI. (2014). Frequently Asked Questions. Retrieved 11/4, 2014, from https://eiti.org/faqs\#WhatEITI

Ernst, Jonathan. (2013). Extractive Industries Transparency Initiative: Results Profile. Retrieved 03/31, 2016, from http://www.worldbank.org/en/results/2013/04/15/extractive-industriestransparency-initiative-results-profile

Esanov, Akram, Raiser, Martin, \& Buiter, Willem. (2001). Nature's blessing or nature's curse: the political economy of transition in resource-based economies. EBRD. London.

Finnemore, Martha, \& Sikkink, Kathryn. (1998). International norm dynamics and political change. International Organization, 52(04), 887-917.

Fox, Jonathan. (2007). The uncertain relationship between transparency and accountability. Development in Practice, 17(4-5), 663-671.

Franke, Anja, Gawrich, Andrea, \& Alakbarov, Gurban. (2009). Kazakhstan and Azerbaijan as post-soviet rentier states: Resource incomes and autocracy as a double 'çurse'in post-Soviet regimes. Europe-Asia Studies, 61(1), 109-140.

Freedom House. (2015). Freedom in the World 2015. Retrieved 02/23, 2015, from https://freedomhouse.org/report/freedom-world/freedom-world2015\#.VOteZ3Y0fP4

Gleason, Gregory. (2010). Natural gas and authoritarianism in Turkmenistan. In I. Overland, H. Kjaernet \& A. Kendall-Taylor (Eds.), Caspian energy politics: Azerbaijan, Kazakhstan and Turkmenistan (pp. 78-89). New York: Routledge.

Graham, Benjamin AT, Johnston, Noel P, \& Kingsley, Allison. (2015). The Capital Effects of Information Voids in Emerging Markets. from http://www.bsg.ox.ac.uk/sites/www.bsg.ox.ac.uk/files/documents/Capital Effects of Information Voids, 8.25.15.pdf

Haas, Peter M. (1992). Introduction: Epistemic Communities and International Policy Coordination. International Organization, 46(1), 1-35.

Hafner-Burton, Emilie M, \& Tsutsui, Kiyoteru. (2005). Human Rights in a Globalizing World: The Paradox of Empty Promises1. American journal of sociology, 110(5), 1373-1411.

Henisz, Witold J. (2002). The institutional environment for infrastructure investment. Industrial and corporate change, 11(2), 355-389.

Hollyer, James R, Rosendorff, B Peter, \& Vreeland, James Raymond. (2014a). Measuring transparency. Political analysis, 22(4), 413-434.

Hollyer, James R, Rosendorff, B Peter, \& Vreeland, James Raymond. (2014b). Why do Autocrats Disclose? Paper presented at the APSA 2014 Annual Meeting Paper. 
Hollyer, James R, Rosendorff, B Peter, \& Vreeland, James Raymond. (2015). Transparency, protest, and autocratic instability. American Political Science Review, 109(04), 764-784.

Huntington, Samuel P. (1993). The third wave: Democratization in the late twentieth century. Norman: University of Oklahoma Press.

Hyde, Susan D. (2011). Catch us if you can: Election monitoring and international norm diffusion. American Journal of Political Science, 55(2), 356-369.

IMF. (2007). Guide on Resource Revenue Transparency. Retrieved 03/20, 2015, from https:/http://www.imf.org/external/np/pp/2007/eng/101907g.pdf

IMF. (2010). Managing Natural Resource Wealth (Draft Program Document).

Islam, Roumeen. (2006). Does more transparency go along with better governance? Economics \& Politics, 18(2), 121-167.

Jensen, Nathan, \& Wantchekon, Leonard. (2004). Resource wealth and political regimes in Africa. Comparative Political Studies, 37(7), 816-841.

Kalyuzhnova, Yelena, \& Bluth, Christoph. (2008). Economics of the Caspian Oil and Gas Wealth: Companies, Governments, Policies. New York: Palgrave McMillan.

Kaufmann, Daniel, Kraay, Aart, \& Mastruzzi, Massimo. (2007). The Worldwide Governance Indicators Project: Answering the Critics". World Bank Policy Research Working Paper No. 4149. Washington, DC.

Keblusek, Mary Ella. (2010). Is EITI really helping improve global good governance?

Kolstad, Ivar, \& Wiig, Arne. (2009). Is transparency the key to reducing corruption in resource-rich countries? World Development, 37(3), 521-532.

Korhonen, Iikka. (2004). Does democracy cure a resource curse? BOFIT- Institute for Economies in Transition Bank of Finland, BOFIT Discussion Papers 18/ 2004.

Lewis-Beck, Michael S, \& Alford, John R. (1980). Can government regulate safety? The coal mine example. American Political Science Review, 74(03), 745-756.

Linden, Ariel. (2015). Conducting interrupted time-series analysis for single-and multiple-group comparisons. Stata Journal, 15(2), 480-500.

Linden, Ariel, \& Adams, John L. (2011). Applying a propensity score-based weighting model to interrupted time series data: improving causal inference in programme evaluation. Journal of evaluation in clinical practice, 17(6), 1231-1238.

Lindstedt, Catharina, \& Naurin, Daniel. (2010). Transparency is not Enough: Making Transparency Effective in Reducing Corruption. International Political Science Review, 31(3), 301-322.

Lipset, Seymour Martin. (1959). Some social requisites of democracy: Economic development and political legitimacy. The American Political Science Review, 53(1), 69-105.

Lomsadze, Giorgi. (2015). Azerbaijan: EITI Downgrade Dents Baku's Image. Retrieved 12/15, 2015, from http://www.eurasianet.org/node/72986

Mahdavy, Hossein. (1970). The patterns and problems of economic development in rentier states: the case of Iran. Studies in the Economic History of the Middle East, 428-467.

March, James G., \& Olsen, Johan P. (1984). The New Institutionalism: Organizational Factors in Political Life. American Political Science Review, 78, 734-749.

Mehlum, Halvor, Moene, Karl, \& Torvik, Ragnar. (2006). Institutions and the Resource Curse. The Economic Journal, 116(508), 1-20. 
Mehlum, Halvor, Moene, Karl, \& Torvik, Ragnar. (2008). Mineral rents and social development in Norway., Prepared for UNRISD project on Financing Social Policy in Mineral-Rich Countries. Geneva.

Meyer, John W., \& Rowan, Brian. (1977). Institutionalized organizations: Formal structure as myth and ceremony. American journal of sociology, 83(2), 340.

Michener, Gregory. (2015). Policy Evaluation via Composite Indexes: Qualitative Lessons from International Transparency Policy Indexes. World Development, 74, 184-196.

OECD. (2014). OECD Foreign Bribery Report: An Analysis of the Crime of Bribery of Foreign Public Officials: OECD Publishing.

Öge, Kerem. (2014). The Limits of Transparency Promotion in Azerbaijan: External Remedies to 'Reverse the Curse'. Europe-Asia Studies, 66(9), 1482-1500.

Öge, Kerem. (2015). Geopolitics and revenue transparency in Turkmenistan and Azerbaijan. Eurasian Geography and Economics, 56(1), 89-110.

Ölcer, Dilan. (2009). Extracting the Maximum from the EITI. OECD Development Centre Working Paper No.276. Retrieved 03/24, 2015, from http://www.oecd.org/dev/42342311.pdf

Peyrouse, Sebastien. (2012). Turkmenistan: Strategies of Power, Dilemmas of Development. London: M.E. Sharpe Inc.

PRS. (2014). International Country Risk Guide. Retrieved 12/25, 2015, from http://www.prsgroup.com/about-us/our-two-methodologies/icrg

Revenue Watch. (2013). Resource Governance Index. Retrieved 12/02, 2013, from http://www.revenuewatch.org/rgi

Rosendorff, B Peter, \& Shin, Kongjoo. (2012). Importing transparency: The political economy of BITs and FDI Flows. from https://files.nyu.edu/bpr1/public/papers/RosendorffShinAPSA2012.pdf

Ross, Michael L. (2001). Does oil hinder democracy? World Politics, 53(3), 325-361.

Ross, Michael L. (2008). But seriously: Does oil really hinder democracy? UCLA Department of Political Science: mimeo.

Scanteam. (2011). Achievements and Strategic Options: Evaluation of the Extractive Industries Transparency Initiative. Retrieved 12/14, 2015, from https://eiti.org/files/2011-EITI-evaluation-report.pdf

Schofer, Evan, \& Hironaka, Ann. (2005). The effects of world society on environmental protection outcomes. Social Forces, 84(1), 25-47.

Simmons, Beth A. (2001). The international politics of harmonization: The case of capital market regulation. International Organization, 55(03), 589-620.

Simonton, Dean K. (1977). Cross-sectional time-series experiments: Some suggested statistical analyses. Psychological Bulletin, 84(3), 489.

Tilcsik, András. (2010). From ritual to reality: Demography, ideology, and decoupling in a post-communist government agency. Academy of Management Journal, 53(6), 1474-1498.

Walter, Andrew. (2008). Governing finance: East Asia's adoption of international standards. Ithaca: Cornell University Press.

Williams, Andrew. (2015). A global index of information transparency and accountability. Journal of Comparative Economics, 43(3), 804-824. 
World Bank. (2013). Worldwide Governance Indicators. Retrieved 08/28, 2014, from http://info.worldbank.org/governance/wgi/index.aspx - home

World Bank. (2014). World Development Indicators. Retrieved 08/28, 2014, from http://wdi.worldbank.org 